\title{
Suburban Patterns under the Influence of Diffused Urbanity
}

\author{
Athina Kiakou \\ Department of Planning and Regional Development, University of Thessaly, Volos, Greece \\ Email:nkiakou@uth.gr
}

How to cite this paper: Kiakou, A. (2021). Suburban Patterns under the Influence of Diffused Urbanity. Current Urban Studies, 9, 609-635.

https://doi.org/10.4236/cus.2021.93037

Received: August 25, 2021

Accepted: September 24, 2021

Published: September 27, 2021

Copyright (c) 2021 by author(s) and Scientific Research Publishing Inc. This work is licensed under the Creative Commons Attribution International License (CC BY 4.0).

http://creativecommons.org/licenses/by/4.0/ (c) (i) Open Access

\begin{abstract}
Nowadays urban development has not been clearly formed. The penetration of urban uses into the rural space constitutes the modern phenomenon of urban "diffusion" and produces an indifferent landscape that leads to the exhaustion of the natural environment. In order to measure the impact of urban diffusion in the suburban landscape, the evolution over time of urban, outof-town land uses along the main roads of Larissa during the period 19982015 is examined. To evaluate the impact of each sector of economic activity, as well as understand the structure of the suburban landscape in terms of land uses patterns, land uses were classified in economic sectors. According to the above processing, a rapid increase in the surface of tertiary sector activities was observed. The construction of stores shows significant growth over the period 1998-2007 and continues to develop until 2015 despite the general economic recession. Furthermore, according to on-site documenting of land uses which took place during 2011-2014, new types of tertiary sector uses were identified. Shopping centres, theme parks, hospitals and colleges located in city fringes, grouped into clusters and constitute the poles of creating new suburban centres. To identify these "new centralities", named as "epicentres", a more detailed classification took place and the observed local clusters were illustrated. However, the epicentres don't have a clear urban character and are less in number and density of uses in relation to the new urban activities of metropolitan centres. Therefore, the creation of special, organized areas for the reception of the emerging "epicentres" and randomly dispersed land uses is suggested. Two wider areas of the suburb are considered as appropriate to install the planned areas for the reception of new developments: the area of Trikala Street and the area of Volos street.
\end{abstract}

\section{Keywords}

Urban Diffusion, Fringe Belts, Land Use Patterns, Cluster, Epicentre 


\section{Introduction}

According to the literature, in the urban diffusion process, the suburban area does not follow any model of development as it is characterized by random dispersion and becomes anarchic. This is not only due to the global economic transformations (de-composition of industrial centres, globalization of the financial sector etc.) but also to the rapid technological and infrastructure development. The predominant trend after the decline of the industry was the location of large commercial investments in areas outside the city and this activity constitutes a crucial factor in the phenomenon of urban sprawl.

In the context of the above developments, new types of tertiary sector use appear as a result of continuous social and economic changes. "Building schemes accommodating, shopping centres, business parks, theme parks, hospitals and colleges located in urban fringes, represent fragments of a "city-centre" that lack an immediately adjacent residential periphery. In this respect, they are city-centre epicentres dispersed in the countryside. Such "new centralities" are radically changing exurban space towards a landscape of diffused urbanity" (Gospodini, 2006).

These new developments in the firm's choice of location have resulted in the conversion of the model of urban, economic activities decentralization (trade, services, culture, etc.), from the known model of peripheral/neighboring centres, as for example the suburb of first-generation (Tachieva, 2011), in a model of linear development along motorways and dispersed development across the entire area of exurban zones (Gospodini, 2006).

"The new exurban landscape transcends North America and Northern Europe. Munoz (2003) documents the existence of such a diffused-urbanity landscape in the fringe belts of Barcelona and other Mediterranean cities" (Gospodini, 2006), including the major metropolitan areas of Athens and Thessaloniki and many medium-sized cities (Larissa, Volos, Kavala, etc.) (Gounaris \& Digridakis, 2005; Gospodini, 2006). "Fringe belts are increasingly covered by detached and semi-detached single family houses, standing alone or being composed in small complexes privately master-planned and dispersed in the countryside. Out-oftown shopping and entertainment malls are also present, close to motorway junctions and orbital peripheral roads in urban fringes" (Gospodini, 2006). In recent years, in the major Greek cities (Athens, Thessaloniki) and in the medium-sized cities (Patra, Volos, Heraklion), autogenous clusters of new urban economies have begun to form.

In order to capture and analyze the new patterns of the suburban landscape of a medium-sized, Mediterranean city under the influence of the above mentioned new developments, the suburb of Larissa is studied. The paper is structured in the following sections:

Methodological issues include the objectives of the research, the questions it poses concerning the change of land uses and the shaping of the new patterns of the suburban landscape which are formed under the influence of the process of 
urban diffusion, as well as the formation of the appropriate tools of urban planning so as to manage urban diffusion. Conceptual issues are also examined and interpreted according to the literature review and in particular, in relation to the new urban uses of the tertiary sector that are concentrated in the suburb under examination. This section also presents the area of the research, which addresses the zones of the main roads of the suburb of Larissa along which the urban uses are developing. The following is the method used for data collection and their processing and analysis in order to examine the evolution of surface over time (1998-2015) and penetration of urban uses into the rural area of Larissa periurban space.

A basic element of the analysis is the tool of land use classification. Thus, legislative tools are used, which are the presidential decrees according to which the uses are classified and grouped into 7 general categories, of which three essentially represent the main sectors of economic activity and the remaining 4 are separate categories.

In the second section, the results of the analysis in maps comparing the land uses of the two different periods 1998 and 2015 for each axis of development of Larissa suburb are presented and commented. This section includes a special subsection where the spatial distribution and local concentrations of units of specific sub-categories of the tertiary sector which prevail, are captured and analyzed. These concentrations of units shape the new epicentres. A total of 7 different spatial categories of epicentres emerge.

In the third section, the basic directions in order to organize the randomly growing uses of the suburb into planned areas so as to limit the anarchic construction and degradation of the rural landscape are proposed. In the end, the final conclusions of the research follow, concerning the diffusion and development of urban uses, the patterns that prevail in terms of economic activities and branches of the tertiary sector but also in terms of morphology and shape of the suburban development. Finally, the general conclusions in relation to the directions on which the master plan to manage this type of urban diffusion should be shaped are formulated.

\section{Methodology}

\subsection{Purpose of Research-Conceptual Issues-Questions}

The main goal of the dissertation is to study the impact of the urban diffusion process in terms of land uses patterns and urban morphology, in a mediumsized, Mediterranean, Greek city of the mainland and finally suggest the appropriate wider areas for the reception of the new land uses, and transform the suburb under study from a space of random dispersed and unorganized land uses into a functional suburban area.

There are different spatial shapes of the urban sprawl phenomenon such as the random distribution, the development of local concentrations of central uses or the expansion of diffusion in major roads. Although urban expansion is irre- 
gular, the dominant trend is along roads that have become the main factor of attraction of central activities (commerce, recreation, etc.). The so-called "octopus form" which is today a model of suburban development of many Mediterranean and Greek cities (Foot, 2000; Munoz, 2003; Gospodini, 2006) was observed as the most important recorded form of diffusion in the region of Larissa (Papakonstantinou et al., 2010), which is the capital of the region of Thessaly.

The documentation of radial urban sprawl in the suburban area of Larissa was based on land uses development, which helps to estimate the impact of the urban diffusion process in the suburban landscape. In order to measure, land use development, the penetration of out of town construction buildings in the countryside was reflected through the evolution of the surface over time of urban, out-of-town land uses developed on either side of major roads of Larissa city. To evaluate the impact of each sector of economic activity, as well as understand the structure of the suburban landscape, land uses were classified into economic sectors.

As in the case of suburbanization, so in the linear developments of the suburban area, the road networks in combination with the initially low acquisition property price and the large land supply attract central activities, which in turn create conditions for urbanization. These conditions attract additional uses such as shops, leisure, housing.

The urban diffusion of the area under survey is also examined through the large "polycentres" located in the city's fringe belts, constituting the cores of new centralities, the so-called "epicentres". The term "polycentre" refers to the concept of the area where many different activities are developed, including trade, in order to attract the public (see consumption and leisure centres in Gospodini, 2006). "They usually accommodate retail stores, multiplex cinemas, cafes, restaurants, public open spaces and amusement parks" (Gospodini, 2006).

According to the classification of the new landscapes of the post-industrial city, there are two basic types of epicentres: the type A of "signifying epicentres" in the inner city where creative clusters forming new urban islands and edges and the type B of "diffused urbanity" in urban fringe which refers in the diffused construction phenomenon in the suburban space (Gospodini, 2006).

The second type is divided into two subcategories:

"1. The exurban new centralities consisting of exurban epicentres for consumption and leisure.

2. The exurban housing dispersal."

The subject of the research in the case of Larissa's suburb is the suburban centres for consumption and leisure. This type of urban development is drawn up by mixing of similar uses, known as "clusters" (groups) of commercial stores, multiplex cinema, cafes, bars, restaurants, theme parks, amusement parks (Gospodini, 2007).

In order to identify the "new centralities" of the examined suburb, a more 
specialized and detailed classification of the observed uses in branches of the tertiary sector was made. Thereafter local accumulations of similar uses belonging to the same branch (the so-called clusters) were identified, aiming to illustrate the new clusters of consumption and leisure which constitute the central "epicentres" of the suburban space.

The above issues are examined through the example of Larissa's fringes which follow the radial development pattern as shown in Figure 1.

In this process, important questions are raised: How can the impact of urban diffusion and penetration in rural areas be captured? What are the main components of the landscape of the urban diffusion in terms of land-use patterns and urban morphology and how could this landscape be classified? What is finally the

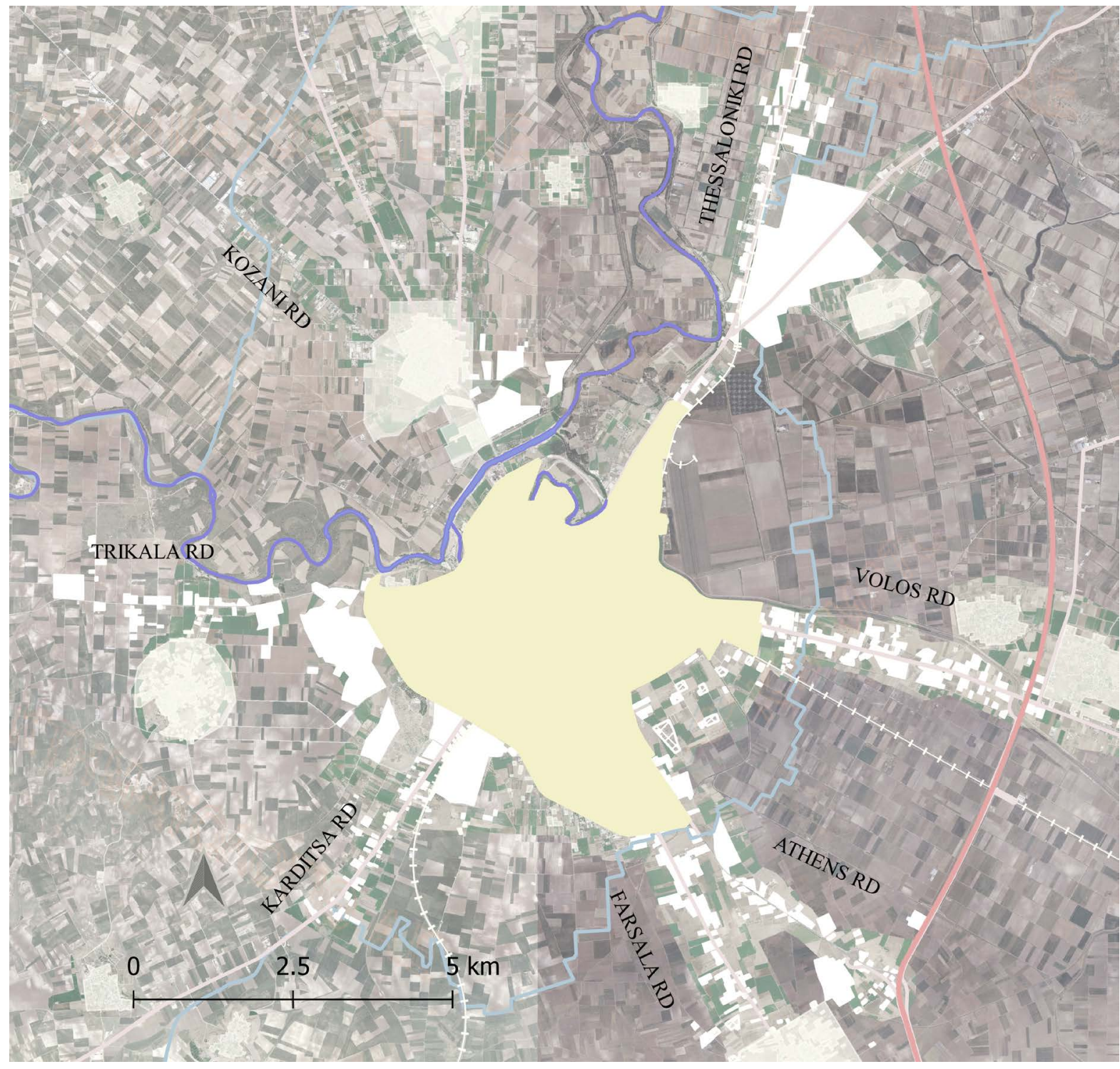

Figure 1. The radial development pattern in Larissa's fridge belts in 2015. Starting from the east and in a clockwise direction: Larissa-Volos Street, the old highway to Athens, Larissa-Farsala Street, Larissa-Karditsa Street, Larissa-Trikala Street, Larissa-Kozani Street and finally the old highway to Thessaloniki. 
appropriate, general context of measures to manage random development of the suburban area and create a functional suburb with respect to the natural environment?

\subsection{Data Collection-Processing}

The demand for out of town construction building has been reflected through the evolution of the surface over time and penetration of urban use into the rural area of Larissa peri-urban space for 17 years, that is for the period 1998-2015. To estimate the impact of land uses in each sector of economic activity, land uses have been classified into economic sectors. A first on-the-spot recording of land uses has taken place and geospatial data collection by satellite geo databases discussed below has been made in order to illustrate the types of land use located in the fringes of the examined suburb.

To identify the new types of tertiary sector uses in the suburb, a second more detailed recording of the tertiary sector enterprises has followed during 20112014. A pre-concerted group has been searched. In particular, 258 business owners were recorded. The enterprises of the tertiary sector that are located along the zones of motorways (fringe belts) in Larissa's suburb were recorded. Larissa's suburb motorways are:

- The road to Farsala (Farsalon) and the old highway to Athens, in the southern suburb of the city,

- The old highway to Volos (Volou) in the east,

- The old highway to Thessaloniki to the north and,

- The roads to Karditsa (Karditsis) and Trikala (Trikalon) in the south-western and western suburbs of the city.

To capture the evolution over time of land uses in the region, material has been gathered from aerial photographs of 12 map sheets of the Hellenic Military Geographical Service (HMGS) taken in1998, from satellite image QuickBird 2008 and from Google Earth satellite imagery (taken in 2007, 2010, 2012, 2013 and 2015). The very high-definition satellite image QuickBird which was taken on the date July 13, 2008, it has been also used as a background for the mapping of uses located along the zone of roads to Volos, Trikala and Karditsa.

The source of Quick Bird and HMGS images has been the aerial photo library of the laboratory of Rural Area of the Department of Planning and Regional Development (DPRD). The other aerial photographs came from the satellite geodatabases Google Earth and from high-resolution geo-database World Imagery of ESRI which was updated on 17.10.2015.

The satellite imagery of Google Earth, the high-definition satellite image of Quick Bird geo-referenced and the geo-databases of ESRI, OpenStreetMap and Topographic, have been used as backgrounds for land use mapping in 2015. Twelve (12) HMGS map sheets taken in 1998, geo-referenced and joined in order to cover the area of the region under study, and have been used for mapping referred to in 1998 . 


\subsection{Land Use Classification}

In Greece land use classification has been based on Presidential Decree (P.D.) of 6.3.1987, until recently. It was the official land use classification system, used by the various types of urban and spatial plans. Since June 29, 2018, the date when P.D. No. 59/21.06.2018 is established, new categories of land use have been foreseen. The research which had been conducted before the new P.D. No. 59/ 21.06.2018 and its subsequent amendments was adopted in 2018, has been based partly on the P.D. of 6.3.1987 which was formed to implement urban planning, and partly on other regulation mentioned bellow. Consequently, its implementation which should have already been specialized thirty years ago since its introduction has not been easy, because nowadays its true interpretation is impossible.

For the above reasons all the relevant regulations have been used, and the relevant categories of uses have been adjusted to the needs of the research. However, subsequently the classification was significantly diversified due to the particularity of the suburban construction building. Due to the different character of the out of town building (more dispersed construction) than the inner-city construction, most categories of uses are limited. Finally, 16 categories of uses have been formed and the appropriate regulation is referred for each category in Table 1.

Attempting to describe the evolution of land use on the main sectors of economic activity, a general classification followed. The above land use categories were grouped together in land uses sectors of economic activity. In this classification, urban uses-installations and not crops (agricultural land) were included. So, the following 7 general categories were formed:

1) Agricultural and livestock facilities category including: greenhouses and agricultural warehouses;

2) Uses of secondary sector category including: crafts-industry, garages-machining, PPC substations;

3) Tertiary sector uses category including: shopping mall, shopping park, retail, residence-fuel station, wholesale, care (clinics, hospitals, boarding school, remediation unit and general health services), Education (primary, secondary and tertiary), recreation, culture, sports, logistics-transport companies, warehouses, Vehicle Technical Control Center, bus station. This category was divided into two subcategories: public and private uses of tertiary sector, because many of the establishments of specialized use (education, health, culture) belong to the government;

4) Residence category: residences included;

5) Special uses category: in this category included utilities such as installations of the Municipal Enterprise for Water Supply and Sewerage (water tanks), biological wastewater treatment, cemetery and camp;

6) Old constructions-Stockyards category, and

7) Vacant construction category. 
Table 1. Land uses classification.

\begin{tabular}{|c|c|c|c|}
\hline $\mathbf{s} / \mathbf{n}$ & Category & Land uses & Regulation \\
\hline 1 & Residence & Residence & $\begin{array}{l}\text { P. D. 23.6-6.3.1987 (Ministry of Environment, Spatial } \\
\text { Planning and Public Works, 1987) }\end{array}$ \\
\hline 2 & Fuel station & Mixed use of fuel station, residence & $\begin{array}{l}\text { P. D. 23.6-6.3.1987, P. D. } 81 / 80 \text { (GG 27/A/29.1.80) } \\
\text { (Ministry of Public Works, 1980) }\end{array}$ \\
\hline 3 & Polycentre & $\begin{array}{l}\text { Commercial stores, multiplex cinema, cafes, } \\
\text { restaurants, playroom, playground, hypermarkets }\end{array}$ & The suburban polycentres under study \\
\hline 4 & Trade & Retail stores, supermarkets, Furniture exhibition & $\begin{array}{l}\text { Article } 5 \text { P.D. of 24-31.5.1985 (Ministry of Spatial } \\
\text { Planning, Settlement and Environment, 1985) } \\
\text { Trade exhibitions category of the P. D. 23.6-6.3.1987 }\end{array}$ \\
\hline 5 & Wholesale & Wholesale Trade Enterprises & Article 7 P.D. 23.6-6.3.1987 \\
\hline 6 & Healthcare & Hospitals, clinics, therapeutic units & $\begin{array}{l}\text { Article } 6 \text { of P.D. 6/17.10.1978 (Ministry of Public } \\
\text { Works, 1978) }\end{array}$ \\
\hline 7 & Education & Infrastructure of Primary, secondary, tertiary education & Article 5 of P.D. 6/17.10.1978 \\
\hline 8 & Leisure Sports & $\begin{array}{l}\text { Night clubs, Restaurants, Audience Areas Sports } \\
\text { facilities, open Stadiums, sport }\end{array}$ & $\begin{array}{l}\text { P.D. 23.6-6.3.1987 } \\
\text { Article } 9 \text { of Presidential Decree 6/17.10.1978 }\end{array}$ \\
\hline 9 & $\begin{array}{l}\text { Logistics-Transport } \\
\text { Companies }\end{array}$ & $\begin{array}{l}\text { Cargo handling companies, freight forwarding } \\
\text { companies, logistics }\end{array}$ & Use category under study \\
\hline 10 & Crafts-Industry & Industrial installations, crafts, Garages-Workshop & Article 4 of P.D. 24/31.5.1985 \\
\hline 11 & $\begin{array}{l}\text { Old } \\
\text { Constructions-Stockyards }\end{array}$ & Vehicle storage fields old constructions & \\
\hline 12 & Agricultural use & Agricultural-food buildings, greenhouses & Article 2 P.D. 24-31.5.1985 \\
\hline 13 & Warehouses & Commercial warehouses, agricultural warehouses & Article 9 P.D. 2431.5.1985 \\
\hline 14 & $\begin{array}{l}\text { Vehicle Technical Control } \\
\text { Center }\end{array}$ & & Article 16 P.D. /6.10.78 (GG 538/D/17.10.78 \\
\hline 15 & $\begin{array}{l}\text { Public Power Corporation } \\
\text { (PPC) Substation }\end{array}$ & $\begin{array}{l}\text { Wider category of "public utilities" PPC -OTE-water } \\
\text { supply }\end{array}$ & $\begin{array}{l}\text { Article } 7 \text { P.D. uses 24-31.5.1985, Article } 14 \text { P.D. } \\
\text { 6.10.78 (GG 538/D/17.10.78) }\end{array}$ \\
\hline 16 & Vacants & Vacant, abandoned buildings & Use category under study \\
\hline
\end{tabular}

In order to identify the new "epicentres", an attempt to analyze the branches of the prevailing sector in the fringe belts was made in combination with the formation of spatial accumulations (clusters) of the suburb and the illustration of the epicentres resulted. To be specific, the tertiary sector uses observed from the on-site recording were classified in spatial accumulations of similar branches, that are the epicentres. Thus, 7 categories of similar uses were created. The above clusters are presented in detail in the section: The Creation of "new centralities".

\section{Results and Discussion}

The historical development of Larissa has created a traditional dispersion of land uses. In recent years large chains of shops have opened branches or have been developed partnerships (franchise), while department stores of regional range (Praktiker, Carrefour, Makro, Jumbo, Smart Outlet, etc.) have been installed. Such department stores follow a completely different model of location from the 
shops downtown. Due to their special needs (large parking spaces, storage areas, extensive facilities) and land costs, they have been installed around the city, in the southwestern districts in out-off-plan areas, such as the peripheral road to Trikala, the road to Volos, the old highway to Athens, and the highway to Kozani (Municipality of Larissa, 2008).

Recently, following the new standards of suburban Polycentres, there is a development of such mixed-use facilities. The concerned Polycentres are a typical case of activities relocation (Delocalization) in areas with a higher land supply (and lower land costs), through the diffusion process of central uses and subsequently the creation of new centres.

As is the case with the commercial transformations of metropolitan areas, land use is linked to traffic or is located in proximity to transport interchanges. In the suburb under study, it is observed the location and creation of polycentres like Pantheon Plaza in the southern edge of the city near the old highway to Athens, the polycentre "Thessaly" (ex-Carrefour-Ster Cinemas) at the $1^{\text {st }} \mathrm{km}$ of road to Kozani and just before the entrance to the settlement of Giannouli and the new polycentre "Larissa", known as Larissa Retail Park located near the Nikaia junction.

These trends of suburbanization and creation of out of town central urban uses create long-term changes in the suburban landscape. A detailed analysis of these developments in each axis of development (fringe belt) follows in the subsequent sections.

\subsection{South Axes Larissa-Athens (Nikaia Junction) and Larissa- Farsala}

The area is central and attracts economic activities of interregional range. A typical example of this trend is the department stores that have been created from 2009 and today constitute the new Polycentre, Retail Park "Larisa". In the area under research prevail commercial uses and hypermarkets (Praktiker, Vassilopoulos). Wholesale activities, schools, leisure and sports facilities are also observed. Activities of secondary sector, large industrial units (Biokarpet, Karatzis A.E., Lariplast) and factories of national range (Melissa, La Vitherm etc.) are also concentrated.

According to the general classification of land uses in the main sectors of economic activity and the land area evolution of each use category (in sqm), the rapid increase of $169.17 \%$ of the surface of tertiary activities is evident in the zone under research (Table 2). Positive change was becoming throughout the period 1998-2015. This positive change was mainly due to the creation of the polycentres of Larissa and the ex-Pantheon Plaza (current Fashion City Outlet) in the area of road Larissa-Athens and some commercial uses in the southern part of the zone of the road to Farsala (Figure 2).

The presence of the residence was also important, and it was already developing (8.29\%) in the suburban area of Nikaia during the period 1998-2015, as well as in the area around Pantheon Plaza shopping mall where it was a dominant use since 1998. Part of the surface of this use was incorporated into the city plan 
Table 2. Land area distribution (sqm) and percentage change per sector of economic activity in the zones extending along the roads Larissa-Farsala and Larissa-Athens.

\begin{tabular}{cccc}
\hline LAND USES & \multicolumn{2}{c}{ Area } & \% Change \\
\cline { 2 - 4 } & \multicolumn{1}{c}{$\mathbf{1 9 9 8}$} & -1.46 \\
Agricultural facilities & $25,488.48$ & $25,116.38$ & 29.32 \\
Secondary sector uses & $521,046.97$ & $673,801.14$ & 169.17 \\
Tertiary sector uses & $417,137.93$ & $1,122,803.09$ & -6.70 \\
Residence & $342,909.93$ & $319,928.14$ & - \\
Residence included in city plan by the General Urban Plan of 2009 & - & $51,423.55$ & 3.29 \\
Total residence & $342,909.93$ & $371,351.69$ & 41.99 \\
Old constructions-Stockyards & $52,509.49$ & $74,559.82$ & 2475.61 \\
Vacants & 4712.09 & $121,365.04$ & 70.57 \\
\hline
\end{tabular}
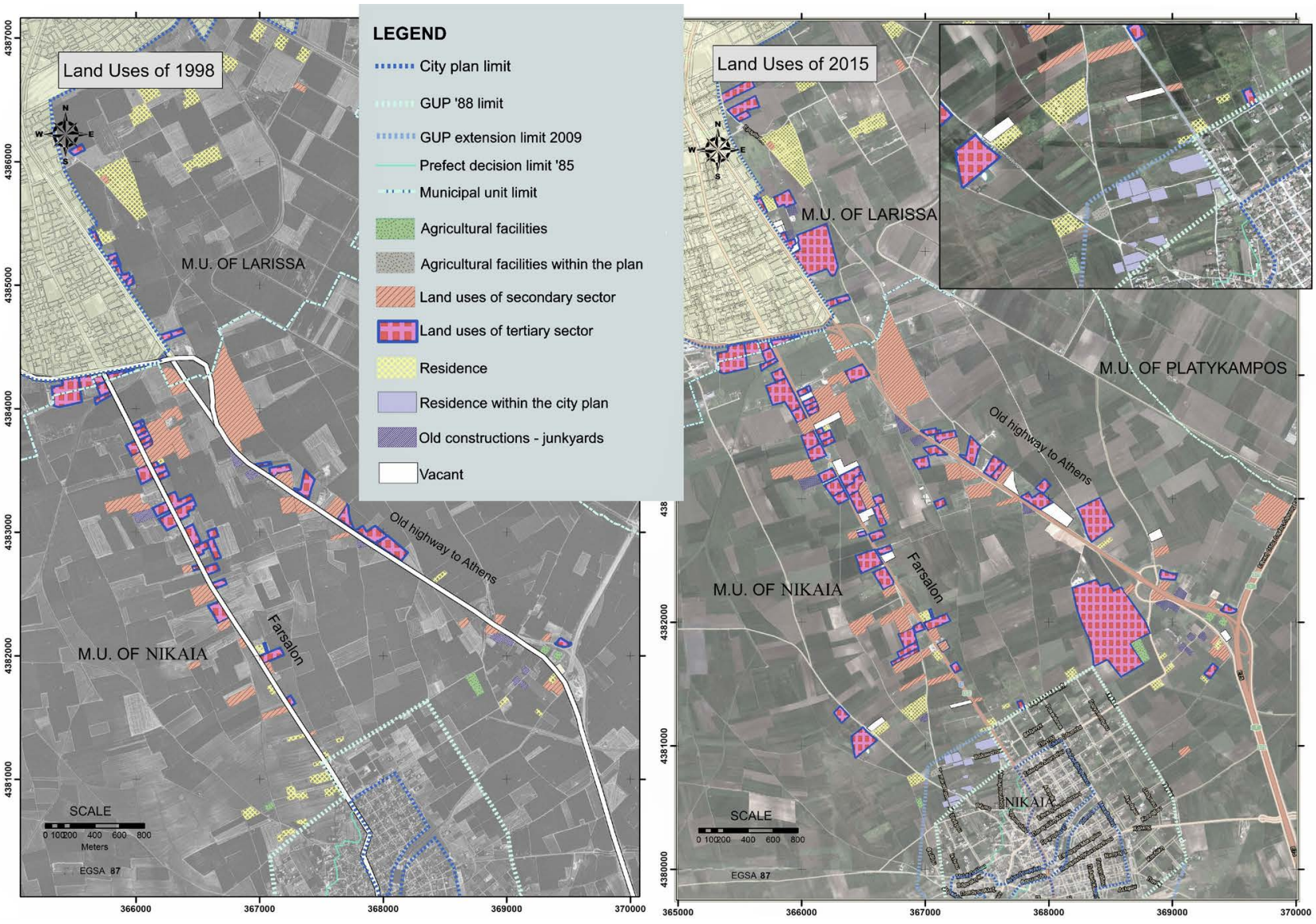

Figure 2. Land uses by sector of activity in the zones extending along the roads to Athens and Farsala in the years 1998 and 2015.

after it had been expanded in 2009.

There was a significant increase in the vacant commercial properties created during the period 2009-2012, as well as old constructions and stockyards (41.99\%). 
The secondary sector had significant growth $(29.32 \%)$ but mainly carried out during the period 1998-2007, as during the period 2007-2015 a relative stagnation took place.

\subsection{Larissa-Karditsa Axis}

At the beginning of this axis (Provincial Road 28), activities of education, health and sport, located in large properties of public sector, operate (Department of Medicine, University Hospital, FC Arena etc). Following the above uses, private investments are developed mainly in the building materials field, furniture and agricultural products branches as far as the $7^{\text {th }} \mathrm{km}$. Most of these uses were included in the urban plan extension area of Larissa General Urban Plan in 2009 (Figure 3).

According to the rate of change of uses per economy sector in this region, as shown in Table 3, significant growth was noted from 1998 to 2015 in housing (29.44\%), in private and public sector investments which almost doubled (96.12\% and $62.66 \%$ respectively), while after the inclusion of these activities in the urban plan area, their positive change diminished technically $(23.25 \%$ and $56.08 \%$ respectively). At the same time, the area shows new special uses (water supply facilities, cemetery) in a land of former military use, resulting in the increase

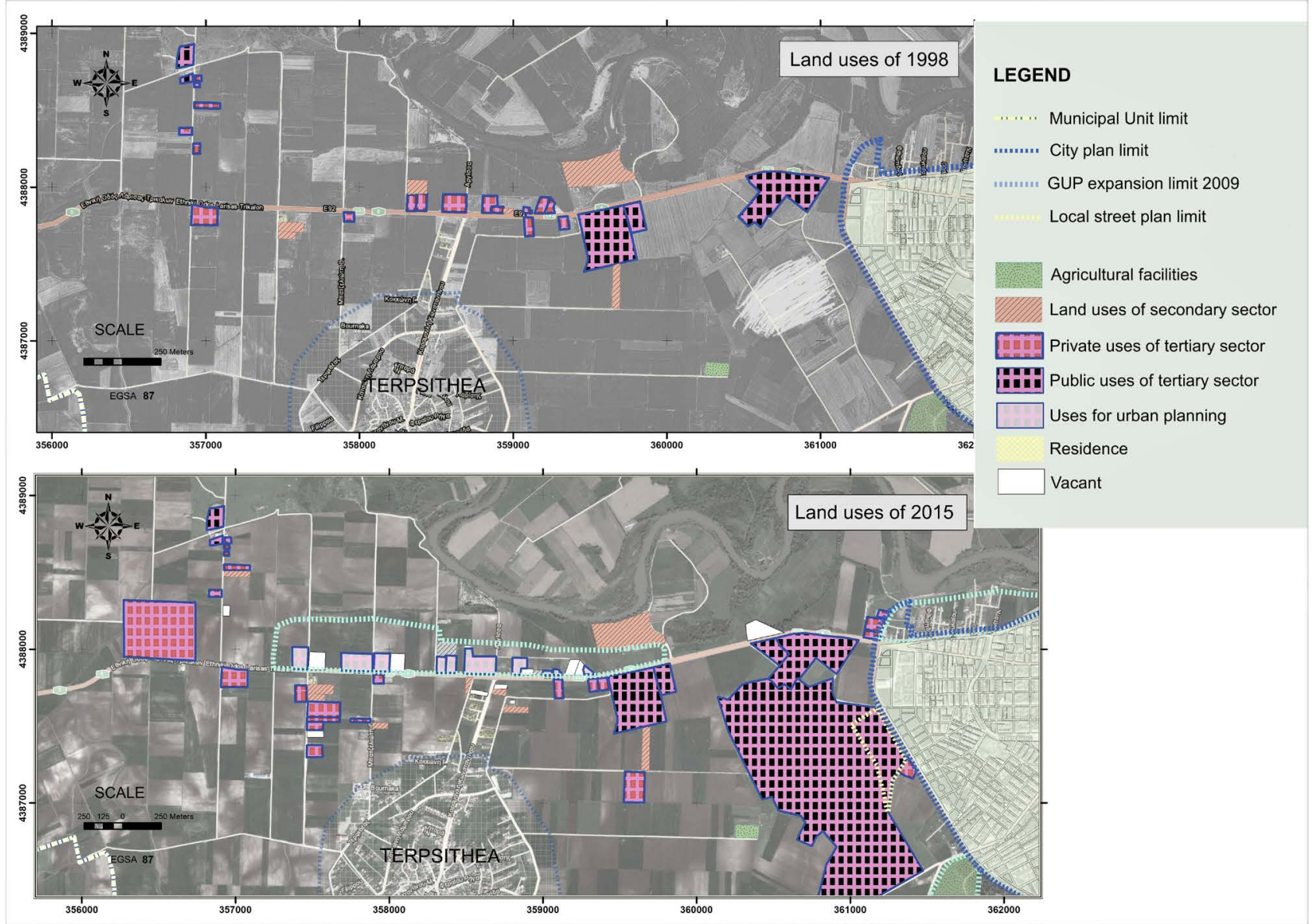

Figure 3. Land uses by sector of activity in the zones extending along the road to Karditsa in the years 1998 and 2015. 
Table 3. Land area distribution (sqm) and percentage change per sector of economic activity in the zone extending along the road Larissa-Karditsa.

\begin{tabular}{|c|c|c|c|}
\hline \multirow{2}{*}{ LAND USES } & \multicolumn{2}{|c|}{ Area } & \multirow{2}{*}{$\begin{array}{l}\% \text { Change } \\
1998-2015\end{array}$} \\
\hline & 1998 & 2015 & \\
\hline Agricultural facilities & 12,468 & $21,630.34$ & 73.49 \\
\hline Secondary sector uses before acceding in an urban plan area & $56,649.97$ & $72,490.26$ & 27.96 \\
\hline Secondary sector uses after acceding in an urban plan area & $56,649.97$ & $62,993.15$ & 11.20 \\
\hline \multicolumn{4}{|l|}{ Tertiary sector uses before acceding in an urban plan area } \\
\hline Private uses of Tertiary sector & 185.934 & 364.653 .5 & 96.12 \\
\hline Public uses of Tertiary sector & $226,876.79$ & $369,027.85$ & 62.66 \\
\hline \multicolumn{4}{|l|}{ Tertiary sector uses after acceding in an urban plan area } \\
\hline Private uses of Tertiary sector & $185,934.02$ & $229,157.67$ & 23.25 \\
\hline Public uses of Tertiary sector & $226,876.79$ & $354,119.93$ & 56.08 \\
\hline Special uses in an urban plan area & 0 & $(715,983)$ & - \\
\hline Residence before acceding in an urban plan area & $29,344.44$ & $60,218.53$ & 105.21 \\
\hline Residence after acceding in an urban plan area & $29,344.44$ & $37,983.20$ & 29.44 \\
\hline Old constructions before acceding in an urban plan area & $31,179.80$ & $31,856.59$ & 2.17 \\
\hline Old constructions after acceding in an urban plan area & $31,179.80$ & $12,110.57$ & -61.16 \\
\hline Vacant before acceding in an urban plan area & 0.00 & $26,641.08$ & - \\
\hline Vacant after acceding in an urban plan area & 0.00 & $12,394.02$ & - \\
\hline Total Land use before acceding in an urban plan area & $542,453.02$ & $1,684,131.51$ & 210.47 \\
\hline Total Land use after acceding in an urban plan area & $542,453.02$ & $1,446,371.88$ & 166.64 \\
\hline
\end{tabular}

of the surface of the special uses in sqm.

\subsection{Larissa-Trikala Axis}

In the western districts, at the city periphery on the road to Trikala and on its outer ring road, significant public investments are developing in the fields of research and education (Departments of Technological Educational Institute, Averofeios School, etc.). The above uses together with the private schools operating in the area (Bakogianni S.A. schools) form an integrated complex of uses of primary, secondary and tertiary education which could constitute a single epicentre of the suburb including education and research uses (Figure 4).

This classification is described in detail in the following section: The Creation of "New Centralities". In the continuation of these activities, private investments are developing mainly operating in the automotive trade.

Regarding the evolution of the studied uses over time, according to Table 4, there is significant growth in private commercial investments $(302.32 \%)$ and the surface they occupy is more than doubled from 1998 to 2015. In total, the area occupied by investments of the tertiary sector shows an increase of $727 \%$. 


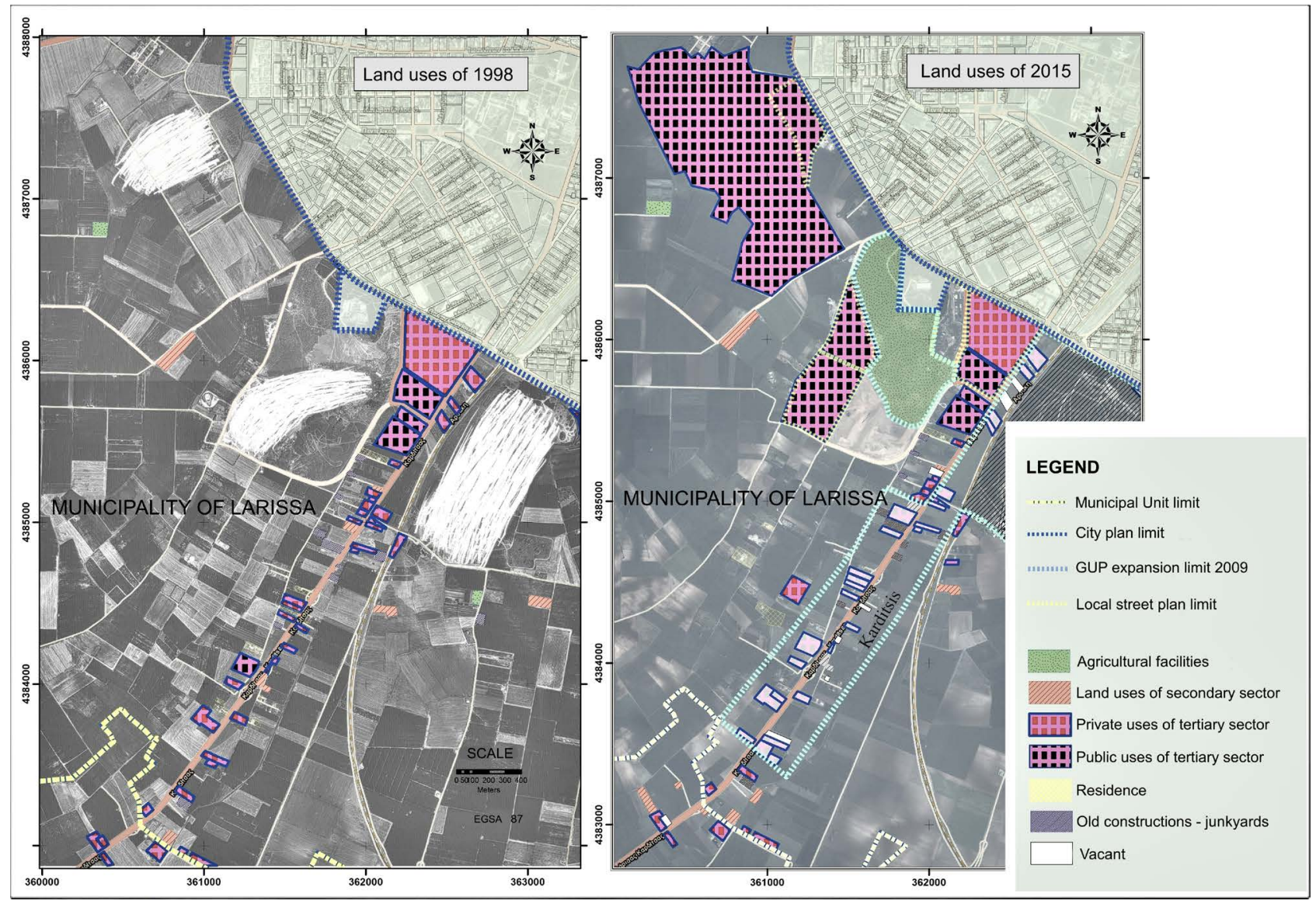

Figure 4. Land uses by sector of activity in the zones extending along road to Trikala in the years 1998 and 2015.

Table 4. Land area distribution (sqm) and percentage change per sector of economic activity in the zone extending along the road Larissa-Trikala.

\begin{tabular}{lccc}
\hline \multirow{2}{*}{ LAND USES } & \multicolumn{2}{c}{ Area } & \% Change \\
\cline { 2 - 4 } & 1998 & 2015 & $1998-2015$ \\
\hline Agricultural facilities & $12,930.13$ & $12,930.13$ & 0.00 \\
Secondary sector uses before acceding in an urban plan area & $117,492.04$ & $142,312.33$ & 21.13 \\
Secondary sector uses after acceding in an urban plan area & $117,492.04$ & $128,369.74$ & 9.26 \\
Tertiary sector uses before acceding in an urban plan area & & & \\
Private uses of Tertiary sector & $109,844.07$ & $441,926.21$ & 302.32 \\
Public uses of Tertiary sector & $264,255.86$ & $1,387,018.167$ & 424.88 \\
Tertiary sector uses after acceding in an urban plan area & & & \\
Private uses of Tertiary sector & $109,844.07$ & $336,342.70$ & 206.20 \\
Public uses of Tertiary sector & $264,255.86$ & $1,387,018.167$ & 424.88 \\
Residence & 7121.69 & $19,032.78$ & 167.25 \\
Vacants & 0.00 & $71,183.20$ & - \\
Total Land use before acceding in an urban plan area & $511,643.79$ & $2,074,402.81$ & 305.44 \\
Total Land use after acceding in an urban plan area & $511,643.79$ & $1,954,876.71$ & 282.08 \\
\hline
\end{tabular}


With the integration of many uses of the private sector in the urban plan according to the proposal of the urban plan extension of the approved General Urban Plan of Larissa (2009), the above percentage declined a little (631.08\%), while the tertiary sector continues to occupy a significant proportion in the land-uses of the region.

Significant growth of $167 \%$ is also noted in the residence due to the development of the Terpsithea settlement, although it is not significantly involved in the percentage composition of the land use surface. On the contrary, the productive activities of the secondary sector have the smallest growth on their surface (21.13\%) before joining the urban plan area).

\subsection{Larissa-Volos Axis}

Along the zone of the road to Volos, commercial development is linked to the traditional industry (furniture, automobile, clothing, and professional equipment). The last one is developing in real estate located some meters behind the old highway to Volos, as shown in Figure 5. The commercial stores are located mainly

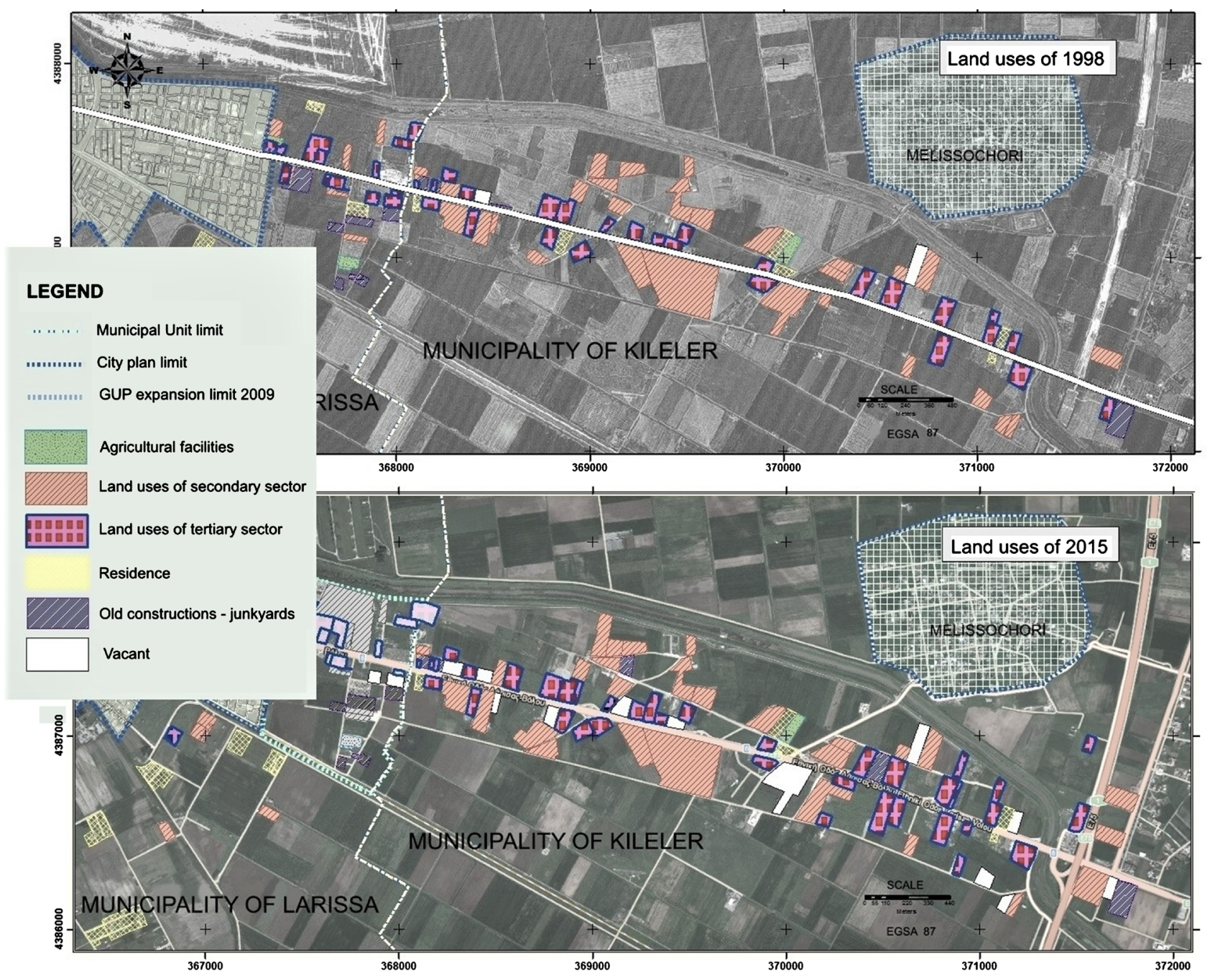

Figure 5. Land uses by sector of activity in the zone extending along the road to Volos in the years 1998 and 2015. 
in real estate near Larissa-Volos axis and they are connected to the road through byways or connections. Retail and wholesale of cars, storage and transfer of products and foodstuffs prevail.

In terms of the development of land uses in this region, according to Table 5, it is observed that tertiary and secondary sector activities are increasing by $38 \%$ and $33.54 \%$ respectively, while the residence surface falls by $40.65 \%$. With the technical reduction created by the extension of the city plan with the creation of an urban planning area as reception area of wholesale uses, the increase in tertiary sector uses is much smaller than before acceding in the urban plan area (7.68\%), but it doesn't correspond to the real development trend of the region.

\subsection{Larissa-Thessaloniki Axis}

In the northern zone of the old highway to Thessaloniki, the traditional industry prevails. From the exit of the city, as far as the first two kilometres, no significant construction is observed, because of the large public areas of the camp, of the forest park and the PPC high voltage substation. In the area the special uses mentioned above, along with the extent of the railroad and PPC, create discontinuities in urban diffusion of the city.

The development is noted after the Sykourio junction and is distinguished between two different production sectors. In the eastern zone that develops along the eastern edge of the old highway to Thessaloniki, industrial and craft-based traditional units are concentrated, the area is an informal industrial zone of the

Table 5. Land area distribution (sqm) and percentage change per sector of economic activity in the zone extending along the road Larissa-Volos.

\begin{tabular}{|c|c|c|c|}
\hline \multirow{2}{*}{ LAND USES } & \multicolumn{2}{|c|}{ Area } & \multirow{2}{*}{$\begin{array}{l}\% \text { Change } \\
1998-2015\end{array}$} \\
\hline & 1998 & 2015 & \\
\hline Agricultural facilities before acceding in an urban plan area & $17,901.09$ & $17,901.09$ & 0.00 \\
\hline Agricultural facilities after acceding in an urban plan area & $17,901.09$ & 8716.94 & -51.30 \\
\hline Secondary sector uses before acceding in an urban plan area & $377,650.93$ & $504,313.57$ & 33.54 \\
\hline Secondary sector uses after acceding in an urban plan area & $377,650.93$ & $418,373.66$ & 10.78 \\
\hline Tertiary sector uses before acceding in an urban plan area & $232,730.17$ & $321,326.09$ & 38.07 \\
\hline Tertiary sector uses after acceding in an urban plan area & $232,730.17$ & $250,599.83$ & 7.68 \\
\hline Residence before acceding in an urban plan area & $46,658.72$ & $41,574.78$ & -10.90 \\
\hline Residence after acceding in an urban plan area & $46,658.72$ & $27,692.27$ & -40.65 \\
\hline Old constructions before acceding in an urban plan area & $58,051.85$ & $77,613.22$ & 33.70 \\
\hline Old constructions after acceding in an urban plan area & $58,051.85$ & $40,635.06$ & -30.00 \\
\hline Vacant before acceding in an urban plan area & 834.69 & $114,833.54$ & $13,657.63$ \\
\hline Vacant after acceding in an urban plan area & 834.69 & $105,457.67$ & $12,534.35$ \\
\hline Total Land use before acceding in an urban plan area & $733,827.45$ & $1,077,562.29$ & 46.84 \\
\hline Total Land use after acceding in an urban plan area & $733,827.45$ & $851,475.43$ & 16.03 \\
\hline
\end{tabular}


city and west, commercial stores of the automobile sector, car agents, spare parts-tires and transporting as well as units of products storage are located (Figure 6).

According to the development over time of land uses of the region, as shown in Table 6, only the tertiary sector activities were developed by $30.23 \%$ during the period 1998-2015. The uses of the secondary sector, even though they occupy
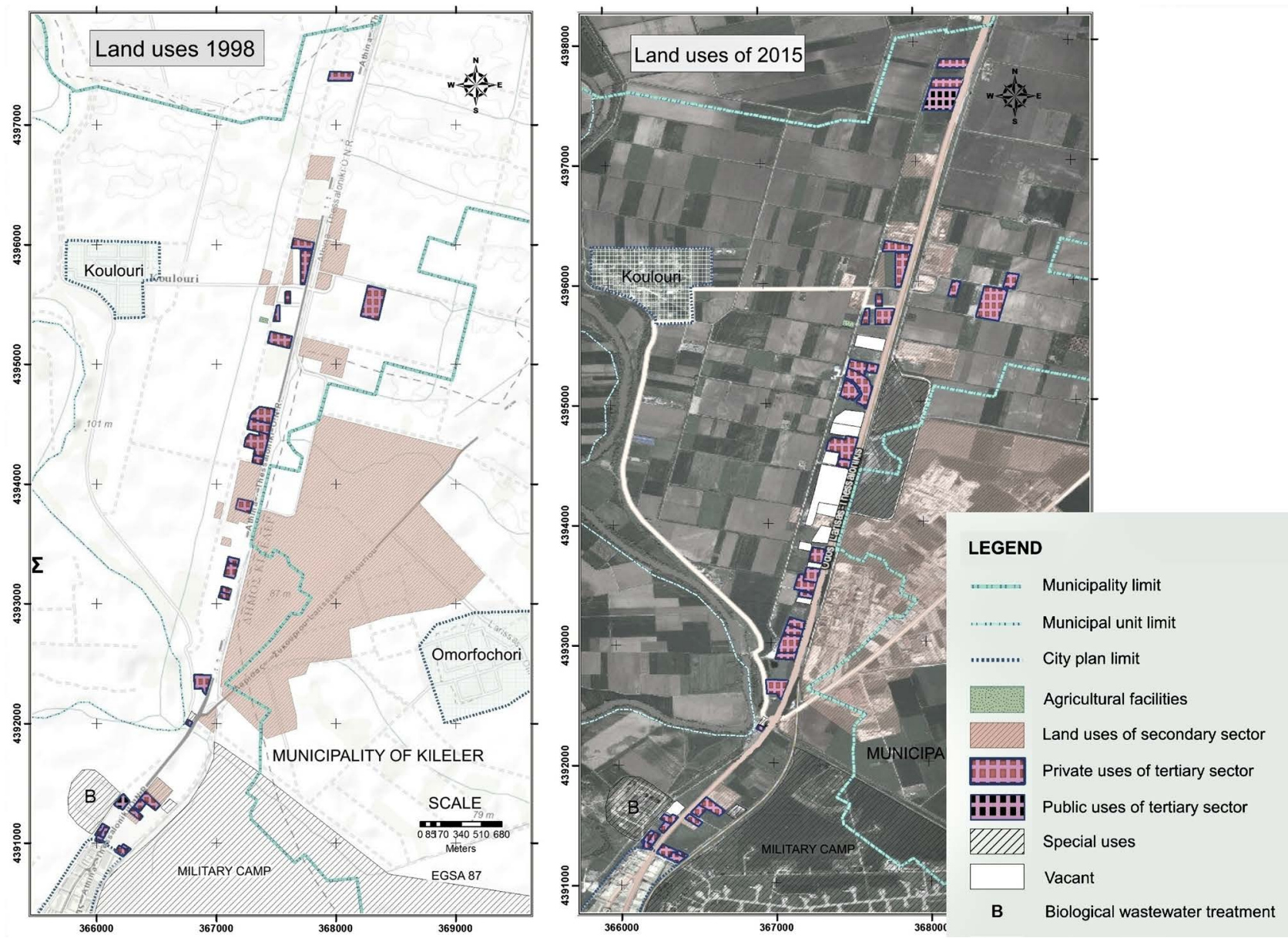

Figure 6. Land uses by sector of activity in the zone extending along the road to Thessaloniki in the years 1998 and 2015.

Table 6. Land area distribution (sqm) and percentage change per sector of economic activity in the zone extending along the road Larissa-Thessaloniki.

\begin{tabular}{cccc}
\hline \multirow{2}{*}{ LAND USES } & \multicolumn{2}{c}{ Area } & \% Change \\
\cline { 2 - 4 } & $\mathbf{1 9 9 8}$ & $\mathbf{2 0 1 5}$ & $\mathbf{1 9 9 8 - 2 0 1 5}$ \\
\hline Agricultural facilities & 2834 & 2834 & 0.00 \\
Secondary sector uses & $3,443,204$ & $3,371,211$ & -2.09 \\
Tertiary sector uses & 325,691 & 424,154 & 30.23 \\
Special uses & $9,883,274$ & $9,521,336$ & -3.66 \\
Vacant & 0 & 182,430 & - \\
Total & $13,655,004$ & $13,501,965$ & -1.12 \\
\hline
\end{tabular}


a significant area, didn't progress (-2\%).

\subsection{The Creation of "New Centralities"}

To classify the urban landscape of the examined suburb and to identify the new clusters of consumption and leisure which constitute the central "epicentres", an attempt to analyze the prevailing branches of the tertiary sector which is the most developed sector in the studied fringe belts, was made. Also, local accumulations of similar branches' land use were identified in order to shape the spatial distribution of the suburban epicenters.

In a specialized classification, the uses of the tertiary sector were divided into clusters of similar commercial branches or other smaller sub-categories all belonging to the tertiary sector as they appear according to a questionnaire survey (Kiakou, 2017) and according to the on-the-spot recording of activities. Of the total of 141 enterprise owners of the region which responded to a related question, a number of 107 are active in retail and wholesale trade, of which 17 are in the production and sale of their product, 3 provide products and services and 34 are service providers. In Table 7 below, the branches of the tertiary sector of the research area with the largest concentration of units are presented.

According to Figure 7, it is observed that the largest development, in number of units, have leisure, car sector, transporting-logistics of goods and furniture. Larissa-Farsala axis is specialized in agricultural machinery, Larissa-Athens axis in leisure uses, Larissa-Thessaloniki axis in car branch, Larissa-Karditsa axis in furniture and building materials and Larissa-Trikala axis in cars and education \& research branches.

The created epicentres include mixed and different combinations of land use' categories from the tertiary sector branches coming from its detailed classification and units coming from the secondary sector according to the general land use classification preceding in the Methodology section. Spatial accumulation of

Table 7. Activities with the largest number of units on the development, out of town axes examined.

\begin{tabular}{|c|c|c|c|c|c|c|c|}
\hline \multirow[b]{2}{*}{ Land use/Branch } & \multicolumn{7}{|c|}{ Number of units } \\
\hline & $\begin{array}{l}\text { Larissa- } \\
\text { Farsala axis }\end{array}$ & $\begin{array}{l}\text { Larissa- } \\
\text { Athens axis }\end{array}$ & $\begin{array}{l}\text { Larissa- } \\
\text { Volos axis }\end{array}$ & $\begin{array}{l}\text { Larissa- } \\
\text { Thessalo-niki axis }\end{array}$ & $\begin{array}{c}\text { Larissa- } \\
\text { Karditsa axis }\end{array}$ & $\begin{array}{l}\text { Larissa- } \\
\text { Trikala axis }\end{array}$ & Total \\
\hline Agricultural machinery-products & 7 & - & 3 & - & 3 & 2 & 15 \\
\hline Food & 6 & 2 & 6 & 1 & 1 & 1 & 17 \\
\hline $\begin{array}{l}\text { Transporting-distribution and storage of } \\
\text { goods }\end{array}$ & 6 & 7 & 5 & 5 & 1 & - & 24 \\
\hline Cars-spare parts-tires & 2 & 2 & 8 & 11 & 1 & 5 & 29 \\
\hline Building materials & - & - & 5 & 1 & 10 & 2 & 18 \\
\hline Furniture & 1 & - & 4 & 5 & 10 & 4 & 24 \\
\hline Education-Research & 3 & - & 1 & 1 & 4 & 7 & 16 \\
\hline
\end{tabular}




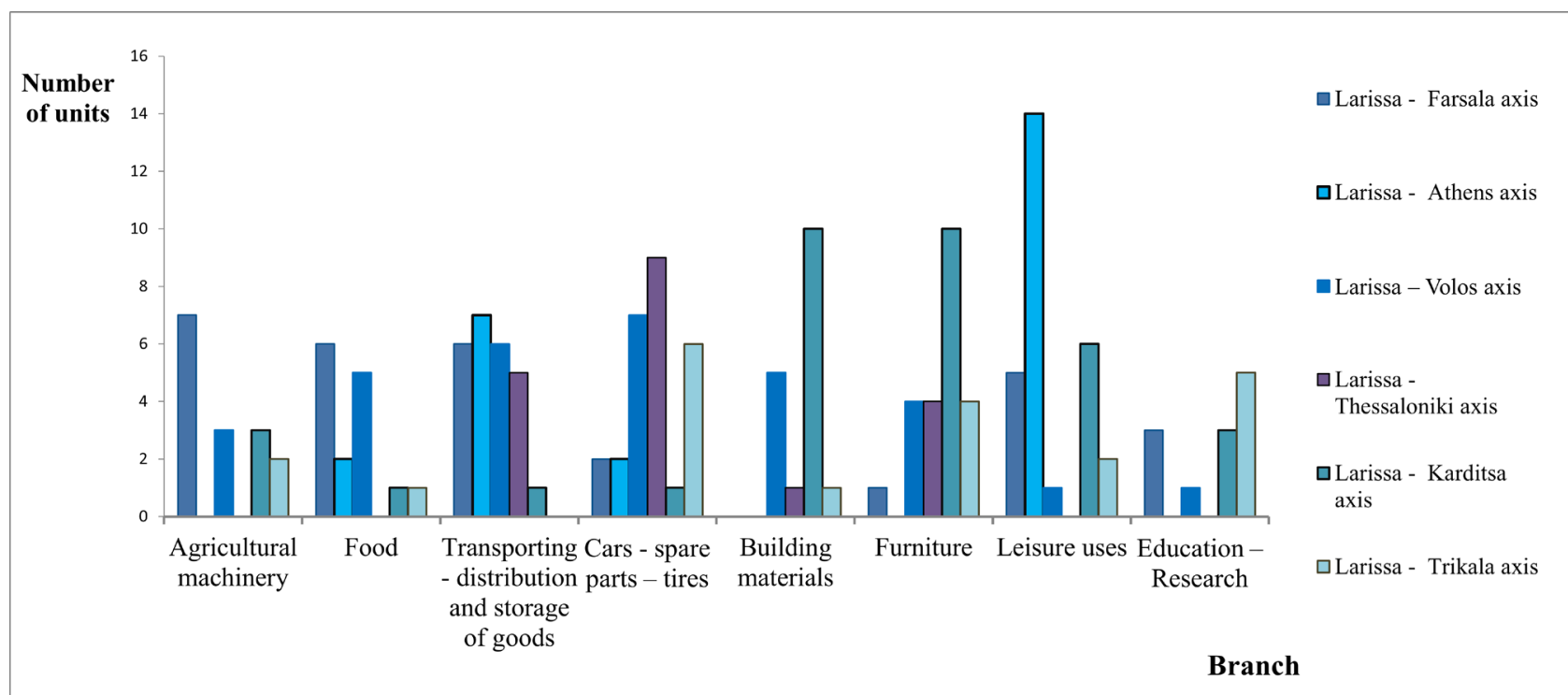

Figure 7. Activities with the largest number of units on the out-of-town axes under examination.

these uses forms the pursued epicentres classified into the following 7 categories:

- Trade-recreation epicentres. They predominate land uses of leisure, sport (sports, restaurants, night clubs, football centers combined with cafés and play areas) and the new polycentres developed along the major road axis which are analyzed above.

- Crafts-industry. It includes purely manufacturers, industrial installations, laboratories, Garages-Workshops.

- Trade-manufacturing epicentres. They include at approximately the same number of secondary production units and commercial stores.

- Trade-wholesale epicentres. They include wholesale and trade shops of various branches.

- Wholesale-recreation epicentres. They include wholesale and recreation shops.

- Trade-offices epicentres. They include commercial shops, private services offices and public services offices.

- Epicentres of education-research. They include either exclusively units of public and private education, or care units in combination with higher education (University Hospital-Medical school).

It is observed that, of the 7 categories of epicentres, 4 are oriented in purely consumption, trade and recreation uses: Trade-recreation epicentres, Trade-wholesale epicentres, Wholesale-recreation epicentres, Trade-offices epicentres and: Education-research epicenters. The created epicentres are illustrated in the following Figures 8-12.

Nevertheless, the "epicentres" which are developed in the region, because of the lack of an urban character and the small scale, are smaller in number and density of uses, in relation to the new urban activities of metropolitan centres, e.g. Athens, Barcelona, Singapore, UK cities, USA etc. (Gospodini, 2006; Hutton, 2000) and they have local urban plans as autogenous uses, but they are un-connected 


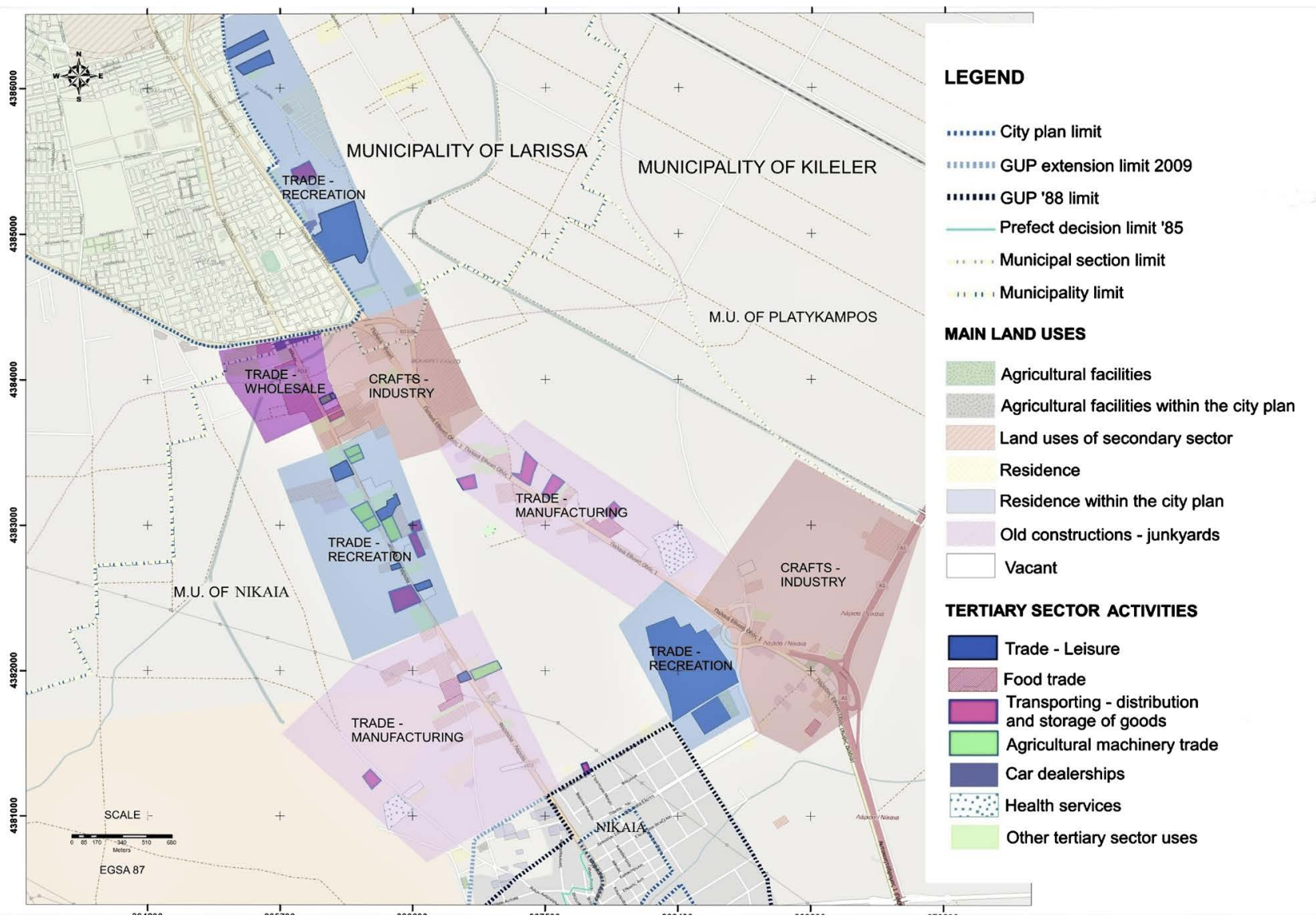

Figure 8. New suburban epicentres in the zones extending along the road to Athens and Farsala.

among each other.

The development of theses clusters has been left to private initiative, which in contrast to the innovative planning of such epicentres in European cities and the suburbs of the third generation in the USA that are competitive and urban organized (Tachieva, 2011), they produce an indifferent landscape that leads to the exhaustion of the natural environment (Gospodini, 2007).

\section{Recommendations}

Observing the historical development of Larissa until the modern post-industrial developments in the fringe belts, the need to organize the produced suburb is created. According to the development trends of the city in terms of land use and population, it is proposed to create special, reception areas which would be installed near the main roads and junctions with whom they would have well connection or/and include the "epicentres" of the area, but not in a random way, as they would be intended and planned to welcome the new modern developments.

The main goal of the project is the transformation of the suburb from a space of random dispersed and unorganized land uses, into a planned suburban area, ensuring the functional development of the suburb and the preservation of the 


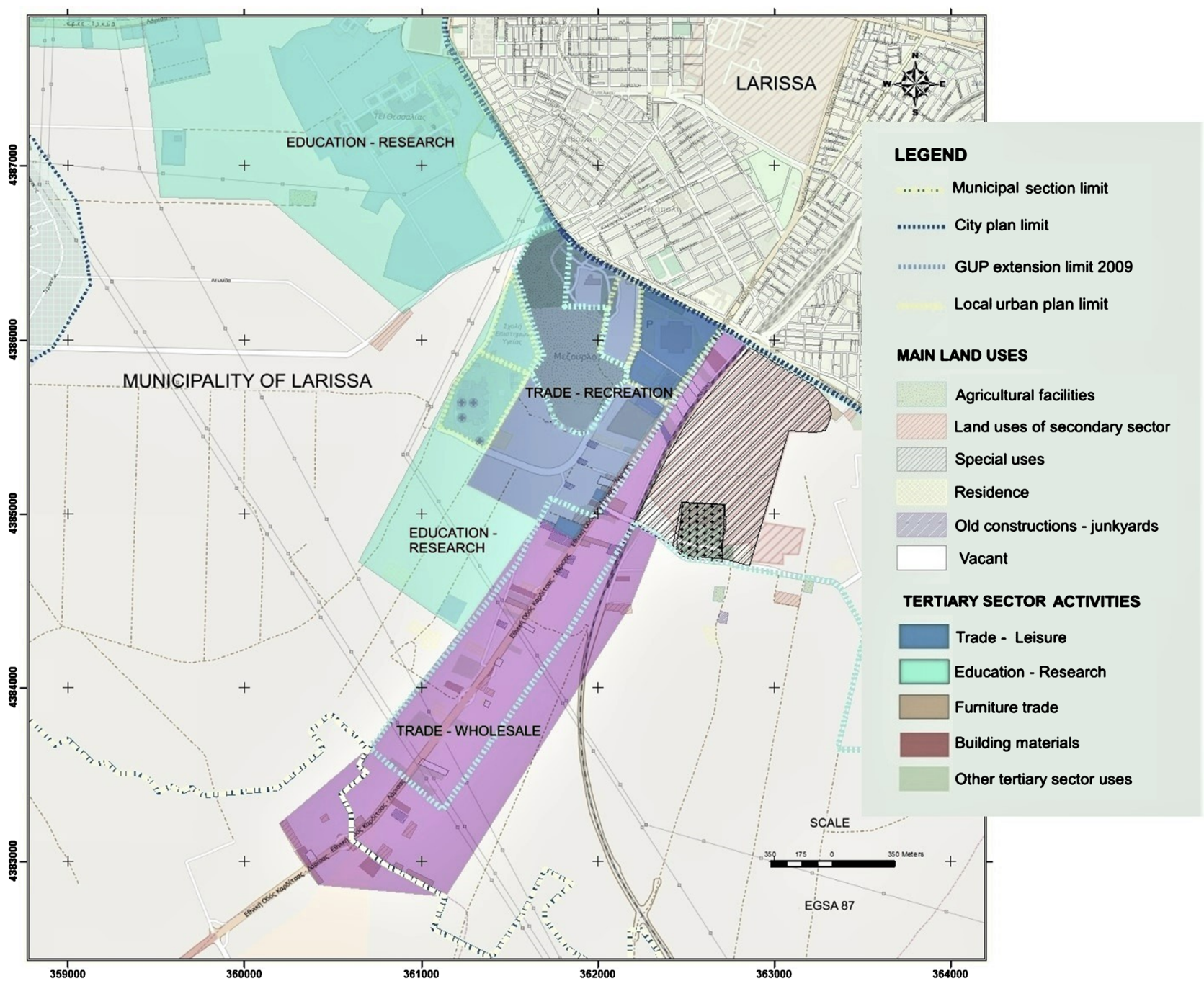

Figure 9. New suburban epicentres in the zone extending along the road to Karditsa.

natural environment.

In the Regional Framework for Spatial Planning and Sustainable Development (RFSPSD) of the region of Thessaly (Ministry of Environment, Planning and Public Works, 2003), the creation of new, properly designed reception areas of central activities, constitute one of the main directions of the planning. According to the General Urban Plan of Larissa, it has been estimated that the size of organized reception areas must be $1000-2000$ acres at the prefecture-level (Tsakiris \& Lalenis, 2009). According to the population forecast for the target year 2025, the trends of uses and urban planning standards, the required areas of central activities reception are calculated, in total, for a time horizon until 2025, equal to 3038 acres (Kiakou, 2017).

It is advisable, however, to examine a location within the municipality, because, on the one hand, there are categories of units that need more direct spatial contact with the main city (either due to their small size or due to decisive dependence on the local market) and on the other hand, this has a reducing effect 


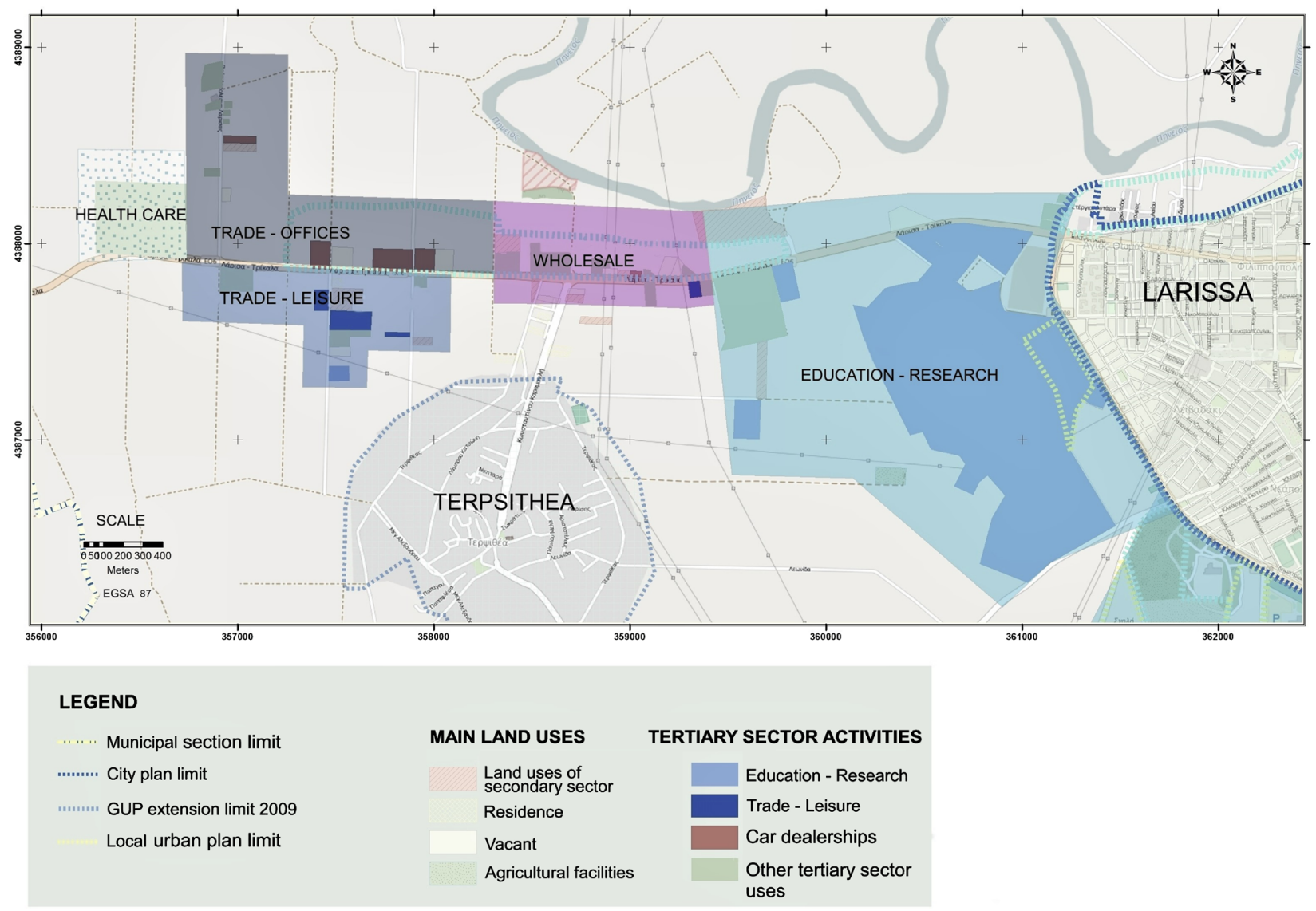

Figure 10. New suburban epicentres in the zone extending along the road to Trikala.

in traffic loads, fuel consumption and the production of gaseous pollutants (Tsakiris \& Lalenis, 2009). The availability of space (suitable areas in terms of geomorphology, existing uses and positions in the overall spatial organization) are important factors in the location selection (Tsakiris \& Lalenis, 2009).

The above factors, as well as the following ones, must be taken into account for the location selection of the reception areas:

- Demand trends for the development of modern activities, as analyzed in the land uses survey.

- The existing infrastructure and the facilities of the suburban area.

- The location of the reception areas in relation to the existing transport and connections network.

- The accessibility to transport infrastructure networks to ensure market access.

- The Special protection areas (ex. Natura 2000).

The areas with the largest development of new activities as it results from the above land uses analysis is the suburban areas extending along the roads to Trikala and Athens. These areas, as shown in the analysis of a special survey conducted on business owners, give a high score in the location of their activity in relation to other cities, the road network and road connections (Biocarpet junction, Nikaia junction, Trikala ring road) that ensure access to these markets 

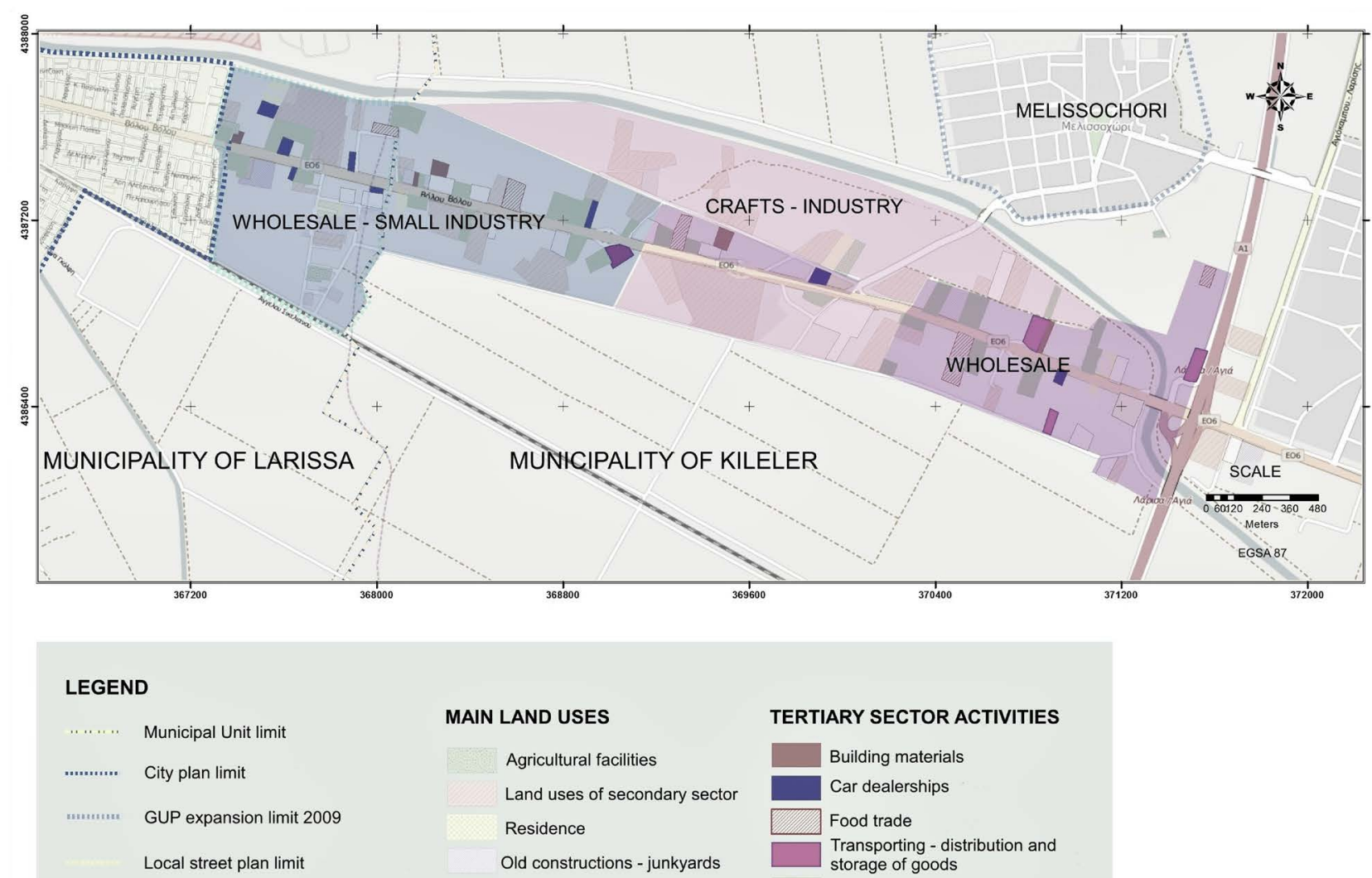

MAIN LAND USES

Agricultural facilities

Land uses of secondary sector

Residence

Old constructions - junkyards

Vacant
TERTIARY SECTOR ACTIVITIES

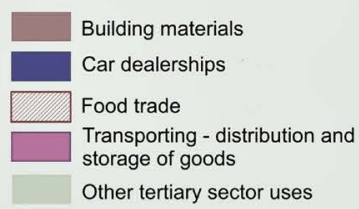

Figure 11. New suburban epicentres in the zone extending along the road to Volos.

(Kiakou, 2017). These areas, also show the highest growth of land values in real estate with view adjacent to the main road (Kiakou, 2017).

In addition to the main reasons for installation in the out-of-plan area, which is the initially low land acquisition price and the supply of land, the area of Trikala Street is chosen by investors according to the questionnaire survey (Kiakou, 2017), because of the demand for the development of tertiary activities, the rural environment and the location in relation to the other cities. It is also an area that has an already developed infrastructure in significant public uses along the ring road zone, the so-called education-research epicentre presented above, and could welcome additional uses of the research and education sector that would be operating together with the existing ones.

Volos street area follows the ranking, showing comparatively smaller growth (positive change) in the surface of tertiary sector land uses in relation to the areas of roads to Athens and Trikala, however, this zone is a choice with a high score by business owners because of the location of the property in relation to the main roads (Kiakou, 2017). The area of Volos Street is connected to the main and to the secondary road network with appropriate infrastructure (connections, side streets, Agia junction).

The area of Volos Street has a long-term perspective to further improve its 


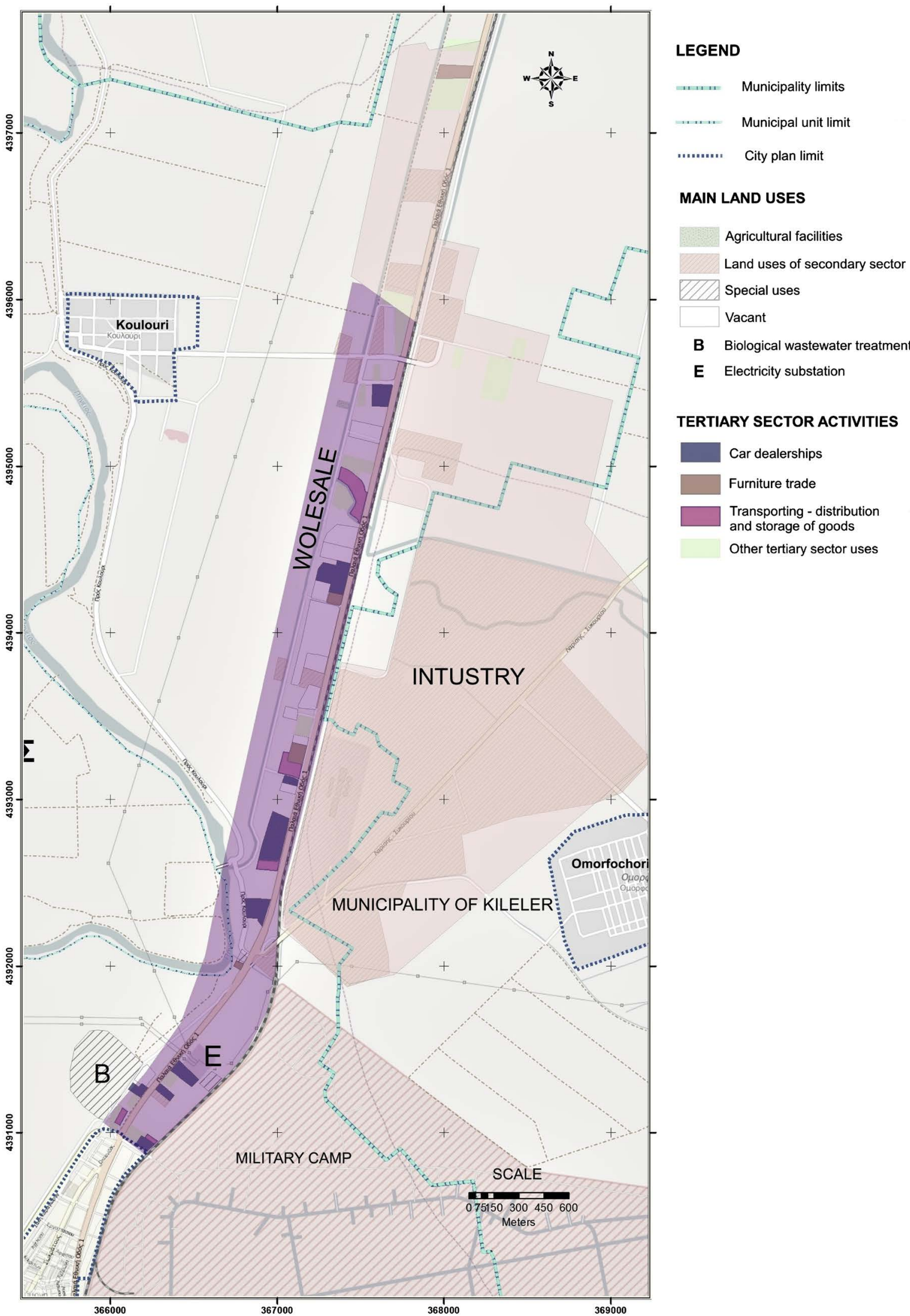

Figure 12. New suburban epicentres in the zone extending along the road to Thessaloniki. 
accessibility to the markets and its connectivity with other road networks. The most important is the existence of a connection between Larissa-Volos dipole, which presents a significant dynamic in the development of activities of interregional range (Metaxas \& Kallioras, 2007).

\section{Conclusion and Discussion}

The historical development of Larissa has created a traditional dispersion of land uses, followed by the modern post-industrial developments in the fringe belts of the city. The surface of urban, out-of-town land uses along the fringe belts of Larissa's suburb during the period 1998-2015, shows significant growth and penetration in rural areas. This development documents the demand's increase for out of town construction buildings especially oriented towards tertiary sector activities such as trade, entertainment and wholesale.

This is evident by the rapid increase in the surface of tertiary sector activities during the examined period. Land supply and its development with the construction of stores show significant growth over the period 1998-2007 and continue to develop until 2015 despite the significant increase in the vacant commercial properties created during the period 2009-2012 that signals the impact of economic recession on the real estate market. Finally, secondary sector activities present stagnation, even though they occupy a significant surface of the observed suburb.

In the southern and western areas of the examined suburb (Larissa-Athens, Larissa-Farsala axes), a significant positive change was noted in the surface of tertiary sector activities throughout the period 1998-2015. This positive change was mainly due to the creation of polycentres, leisure and commercial activities of interregional range.

In the western districts, at the city periphery on zones of the roads to Karditsa and Trikala and its outer ring road, significant public and private investments have been developed in the fields of research and education and health. The above uses along with the private schools which could operate in an integrated complex of uses of primary, secondary and tertiary education, could constitute a single epicentre of the suburb.

Regarding the private investments of the suburb, development trends of automotive industries, logistics, retail, entertainment and furniture are observed. Also, the public sector contribution to the fields of education, health and research is important. The car sector, transportation-logistics of goods and furniture concentrate the largest number of units, but in some areas and particularly in the western and southern suburbs the uses of education and leisure fields present the largest development in terms of the land surface.

Regarding the morphology of the suburban landscape, although the linear development model dominates as a consequence of the attraction of the road infrastructure, at the same time it's also observed the type B of "diffused urbanity" (Gospodini, 2006) without following always the radial development pattern. So, 
Larissa would be said to be broadly approaching the radial model but in combination with the polycentric model, which is expressed unplanned not in a regular way, through type B of epicentres of "diffused urbanity".

There are clusters of similar uses of the so-called "new centralities" or "epicentres" on the fringe belts of the city and also, there are accumulations of the new central activities located peripherally in the peri-urban zone of the city, as in the case of uses near the Trikala ring road where the epicentres of education and research prevail. Nevertheless, in any case, land use development follows always the proximity to road infrastructure.

Analyzing the prevailing branches of the tertiary sector according to their spatial distribution, the new "epicentres" of central land uses of the suburban space are formed. Totally, 7 categories of epicentres were identified, of which 4 is oriented in purely consumption and trade uses: Trade-recreation epicentres, Trade-wholesale epicentres, Wholesale-recreation epicentres, Trade \& offices epicentres and Education \& research epicentres that include special uses of education and research.

However, the epicentres of the region don't have an urban character, they include a small number of dispersed uses which are urban unplanned and unconnected among each other. All the above-mentioned developments, create an indifferent landscape leading to the exhaustion of natural environment. Consequently, the need to organize the suburb in the fringe belts of the city is created.

According to the advantages of each region of development in the suburb under study, two candidates wider regions resulted, in order to install the planned areas for the reception of new developments:

a) The area of Trikala Street, which is chosen because of the demand for the development of tertiary activities, the rural environment the location in relation to the other cities but also, the already existing developed infrastructure in significant public uses along the ring road zone, the so-called Education-research epicentre, and

b) Volos street area which although follows the ranking, showing comparatively smaller growth in the surface of tertiary sector land uses in relation to the areas along the roads to Athens and Trikala, it has a long-term perspective to further improve its accessibility to the markets and its connectivity with other road networks. But, the most important is the existence of a connection between Larissa-Volos dipole that attracts activities of interregional range.

Regarding the limitations of the research, there are geographical constraints, restrictions concerning the characteristics of the area where enterprises developing and the type of economic activity as well as restrictions related to the current legislative framework.

At the spatial level, this paper analyses the suburban patterns in terms of land uses and morphology of a Mediterranean medium-sized city of the mainland. The wider research, in order to deal with phenomena of anarchic urbanization, may deal with different sectors of economic activity and urban areas of different 
morphology and development patterns such as coastal zones, tourist areas, areas with high population and economic concentration or large metropolitan centres. In terms of geography, therefore, each case is different and the research should be adapted to the particular spatial and morphological data of each area. Thus, data collection must be differentiated and oriented to these economic sectors and areas presenting trends of development (e.g. tourist units of a coastal zone) or must take into account specific limitations (e.g. protection zones, etc.). Except for natural and geographical particularities, generally, land uses development is connected to the transport networks and most of the time, road networks.

Additionally, the categorization and classification of land uses differs depending on the sample size, that is the number of activities presented, the type of economic activity, and the characteristics of the area where enterprises developing during the detailed recording. For example, within a metropolitan city, clusters of similar uses have a more cohesive character due to the character of the inner tissue of the city, in contrast to the suburb of a medium-sized city, such as the suburb of Larissa, where the areas of activities lack an urban plan and activities are sparsely structured. In summary, this research is limited mostly to the classification and management of randomly growing uses in the suburbs.

Land use classification also differs due to the different legislative framework of each country. Each country has different regulations for the categories and classification of activities. In addition, the classification of uses must take into account the specific uses observed in each region and whether these special uses are provided by the legislation of each country or not. For example, in Greece, "polycentres" were not provided for in the old presidential decree.

Therefore, in the context of creation of a master plan or of a policy in order to manage urbanization, the above restrictions must be taken into account. As far as the factors mentioned in the Recommendations section, for determination of the new land uses reception area location, most of these factors can be generalized in order to create a policy that directs the demand for construction. However, in some cases, like in Greece, most of the time, planning follow trends and in that case, the demand for the development depends on trends of development of each region and its location in relation to the city (inner tissue of the city, city's periphery or out-of-city plan area) and the connections (road or other networks) with the city and the other cities and markets.

\section{Conflicts of Interest}

The author declares no conflicts of interest regarding the publication of this paper.

\section{References}

Foot, J. (2000). The Urban Periphery, Myth and Reality: Milan 1950-2000. City, 4, 7-26. https://doi.org/10.1080/713656994

Gospodini, A. (2006). Portraying, Classifying and Understanding the Emerging Landscapes in the Post-Industrial City. Cities, 23, 311-330. 
https://doi.org/10.1016/j.cities.2006.06.002

Gospodini, A. (2007). Urban Environment and New City. Invited Public Speech, Institute of Strategic \& Development Studies-Andreas Papandreou (ISTAME) and Association of Greek Urban Planners (SEPOCH).

Gounaris, X., \& Digridakis, Ch. (2005). Greece of Shopping Centres. The World of Investor. Daily Financial Newspaper.

Hutton, Th., A. (2000). Reconstructed Production Landscapes in the Postmodern City: Applied Design and Creative Services in the Metropolitan Core. Urban Geography, 21, 285317. https://doi.org/10.2747/0272-3638.21.4.285

Kiakou, A. (2017). The "Urban Sprawl” Effect on Out-of-Town Real Estate Market. Open Science Journal, 2, 1-22. https://doi.org/10.23954/osj.v2i4.1032

Metaxas, T., \& Kallioras, D. (2007). Medium-Sized Cities' Development and Regional Competitiveness: The Case of Larissa-Volos Dipole in the Region of Thessaly, Greece. Review of Economic Sciences, 12, 115-136.

Ministry of Environment, Spatial Planning and Public Works (1987). Presidential Decree of 6.3.1987. Categories and Content of Land Uses. GG-166/A/1987, National Printing Office.

Ministry of Public Works (1978). Presidential Decree of 6.10.78. about Defining Building Conditions and Restrictions of the Plots Located Out of the City Plans and Out of the Legal Boundaries of Existing, Before the Year 1923, Settlements. GG 538/D/17.10.78, National Printing Office.

Ministry of Public Works (1980). Presidential Decree of 81/80. About Special Land Uses and Maximum Limits of Permitted Exploitation of Buildable Spaces. GG 27/A/29.1.80, National Printing Office.

Ministry of Spatial Planning, Settlement and Environment (1985). Presidential Decree of 24/31.5.1985. Out-of-Plan Building. GG-270/D/31.5.1985, National Printing Office.

Ministry of Environment, Planning and Public Works (2003). Approval of the Regional Framework for Spatial Planning and Sustainable Development (RFSPSD) of the Region of Thessaly. Decision No 25292/25.6.2003. GG 25292 /10.10.2003, National Printing Office.

Municipality of Larissa (2008). Operational Program of the Municipality of Larissa 20082011, Phase A, Strategic Planning. Municipality of Larissa, p. 459.

Munoz, F. (2003). Lock Living: Urban Sprawl in Mediterranean Cities. Cities, 20, 381-385. https://doi.org/10.1016/j.cities.2003.08.003

Papakonstantinou, S., Faraslis, I., \& Stathakis, D. (2010). Diachronic Study of Suburban Land Uses of Larissa (p. 14). Master Degree in Planning and Regional Development, University of Thessaly.

Region of Thessaly (2009). Review and Extension of the General Urban Plan (GUP) of the Municipality of Larissa Approval. Decision No. 5625/59708. GG 523/9.10.2009, National Printing Office.

Tachieva, G. (2011). Sprawl Repair, from Sprawl to Complete Communities. Terrain org, No. 28, 9. http://www.terrain.org/articles/28/tachieva.htm

Tsakiris, St., \& Lalenis K. (2009). General Urban Plan of Larissa, B2 Phase. Municipality of Larissa. 